\title{
Stanowisko zespołu ekspertów Polskiego Towarzystwa Alergologicznego i Polskiego Towarzystwa Dermatologicznego w sprawie wytycznych postępowania w pokrzywce*
}

\author{
Komentarz do: Zuberbier T, Aberer W, Asero R et al. The EAACI/GA² LEN/EDF/WAO \\ Guideline for the definition, classification, diagnosis, and management of urticaria: \\ the 2013 revision and update. Allergy 2014; 69: 868-887
}

\author{
Zbigniew Bartuzi', Zenon Brzoza ${ }^{2}$, Magdalena Czarnecka-Operacz ${ }^{3}$, Jerzy Kruszewski ${ }^{4}$, Joanna Maj ${ }^{5}$, \\ Zbigniew Samochocki ${ }^{6}$, Bolesław Samoliński ${ }^{7}$, Jacek Szepietowski ${ }^{5}$

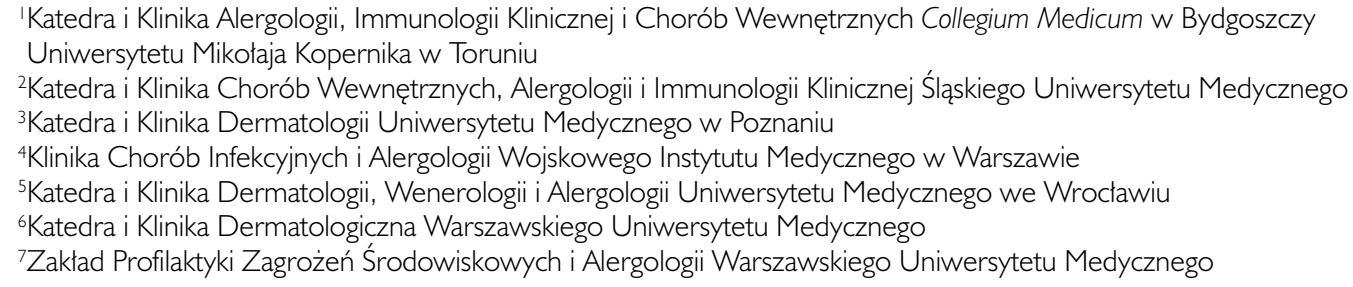

Zespół ekspertów Polskiego Towarzystwa Alergologicznego i Polskiego Towarzystwa Dermatologicznego jednomyślnie uznaje, że nowe, międzynarodowe wytyczne dotyczące postępowania w pokrzywce całkowicie spełniają wymagane kryteria i można je uznać za obowiązujące w Polsce. Eksperci wymienionych towarzystw opatrują tekst międzynarodowych wytycznych poniższym komentarzem, który może być przydatny w analizie dokonanych zmian $\mathrm{w}$ zaleceniach oraz ich interpretacji w realiach klinicznych naszego kraju.

Nowo opublikowane wytyczne przedstawiają definicję, aktualny podział oraz zasady postępowania diagnostycznego i terapeutycznego w pokrzywce. Są one efektem pracy międzynarodowego zespołu ekspertów i interaktywnej dyskusji z członkami spotkania "Urticaria 2012”, które odbyło się w Berlinie w dniach 28-29 listopada 2012 roku [1]. Niniejszy dokument w zwięzły sposób przedstawia aktualny stan wiedzy i wprowadza pewne zmiany w stosunku do wcześniej obowiązujących opracowań [2].

Przede wszystkim zwraca uwage nowy podział pokrzywki przewlekłej. Obok pokrzywki przewlekłej spontanicznej wyróżniono grupę pokrzywek indukowalnych, w skład której wchodzą postaci pokrzywki określane w poprzednich wytycznych jako fizykalne oraz tzw. inne typy pokrzywki [2]. Jak wynika $\mathrm{z}$ aktualnego podziału, nadal często spotykany termin pokrzywka przewlekła idiopatyczna zawiera się w definicji pokrzywki przewlekłej spontanicznej (ryc. 1), co jest szczególnie warte podkreślenia z uwagi na sformułowania zawarte we wskazaniach rejestracyjnych stosowania leków przeciwhistaminowych (tab. 1).

Omawiany dokument podkreśla konieczność oceny jakości życia pacjentów z pokrzywką, zwłaszcza w kontekście opracowania specyficznego dla pokrzywki przewlekłej kwestionariusza oceny jakości życia CU-QoL [3]. Należy podkreślić, że dysponujemy obecnie w pełni zaadaptowaną polską wersją tego kwestionariusza, chociaż nie umniejsza to znaczenia i roli dostępnych już wcześniej dermatologicznych skal oceny jakości życia, takich jak Skindex oraz DLQI, ze względu na wieloletnie doświadczenia w korzystaniu i znajomość tych instrumentów [4].

W kolejnych częściach dokumentu przedstawione są badania diagnostyczne, które powinny być brane pod uwagę $\mathrm{w}$ postępowaniu $\mathrm{z}$ chorymi na

\footnotetext{
*Nazwy towarzystw wymieniono w kolejności alfabetycznej.

Opublikowano za zgodą Polskiego Towarzystwa Alergologicznego i Polskiego Towarzystwa Dermatologicznego.
} 


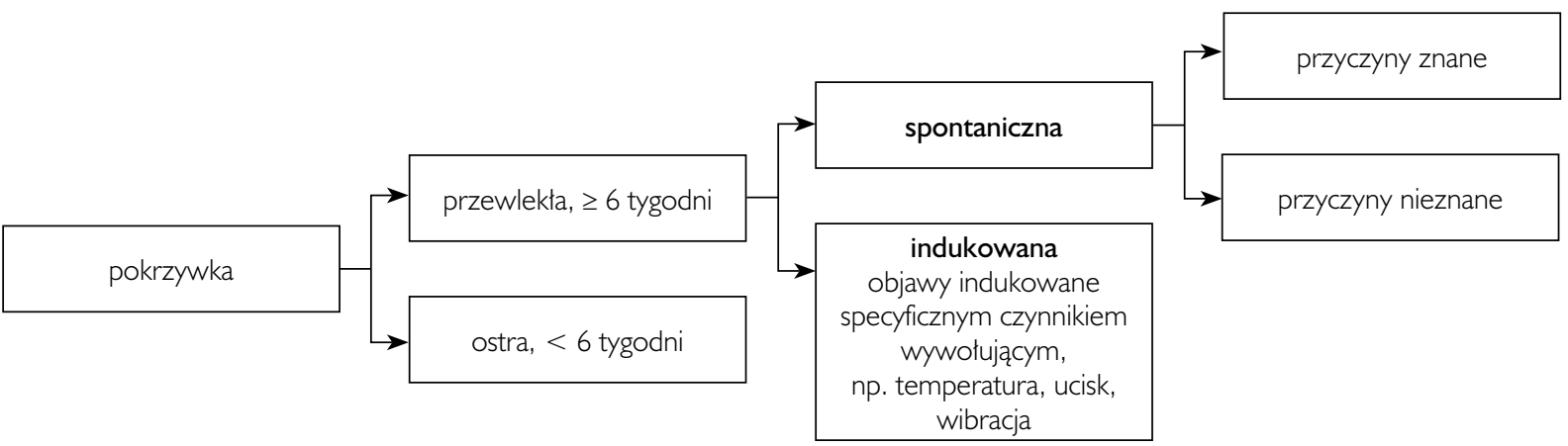

Rycina I. Aktualny schemat podziału pokrzywki [I]

Figure I. The current scheme of division of urticarial [I]

Tabela I. Zestawienie leków przeciwhistaminowych drugiej generacji wg zarejestrowanych wskazań w leczeniu pokrzywki z uwzględnieniem progów wiekowych

Table I. Summary of the second-generation antihistamines according to approved indications in the treatment of urticaria taking into account the age thresholds

\begin{tabular}{|c|c|c|}
\hline $\begin{array}{l}\text { Lek przeciwhistaminowy } \\
\text { drugiej generacji }\end{array}$ & Wskazanie wg Charakterystyki produktu leczniczego (ChPL) & Próg wiekowy wg ChPL \\
\hline bilastyna* & objawowe leczenie pokrzywki & powyżej 12. roku życia \\
\hline cetyryzyna* & łagodzenie objawów przewlekłej pokrzywki idiopatycznej & powyżej 2. roku życia \\
\hline desloratadyna* & łagodzenie objawów związanych z pokrzywką & powyżej I. roku życia \\
\hline feksofenadyna* & objawowe leczenie przewlekłej pokrzywki idiopatycznej & powyżej 12. roku życia \\
\hline lewocetyryzyna* & objawowe leczenie pokrzywki & powyżej 2. roku życia \\
\hline loratadyna* & objawowe leczenie przewlekłej pokrzywki idiopatycznej & powyżej 2. roku życia \\
\hline rupatadyna* & objawowe leczenie pokrzywki & powyżej 12. roku życia \\
\hline
\end{tabular}

*Zamieszczone dane odpowiadają informacji rejestracyjnej oryginalnych produktów leczniczych, tj. odpowiednio: Bilaxten, Zyrtec, Aerius, Telfast, Xyzal, Claritine, Rupafin.

pokrzywkę. Chcemy jednak zauważyć, że niektóre z wymienionych metod nie są powszechnie dostępne i w części przypadków konieczne jest kierowanie pacjentów do wyspecjalizowanych ośrodków w celu przeprowadzenia poszerzonej diagnostyki. Zaprezentowany został ponadto algorytm przejrzyście przedstawiający poszczególne etapy postępowania diagnostycznego. Warto podkreślić zwłaszcza konieczność uwzględnienia $\mathrm{w}$ diagnostyce pacjenta ze zmianami pokrzywkowymi zespołów autozapalnych, które - choć bardzo rzadkie - są zdecydowanie niedorozpoznawane. Autorzy wytycznych zwracają ponadto uwagę na możliwość nawracania przez pewien czas zmian chorobowych nawet po odstawieniu leku u pacjentów z obrzękiem naczynioruchowym prowokowanym preparatami z grupy inhibitorów konwertazy.

Aktualne wytyczne w sposób zwięzły i przejrzysty przedstawiają algorytm leczenia przewlekłej pokrzywki, uwzględniając stosowanie ponadstandardowych dawek leków przeciwhistaminowych drugiej generacji oraz interwały intensyfikacji leczenia. Zdecydowanie przychylamy się do propozycji zwiększania dawki leków przeciwhistaminowych drugiej generacji przy braku uzasadnienia dla jednoczesnego stosowania różnych preparatów leków przeciwhistaminowych zarówno należących do drugiej generacji (sumowanie się działań niepożądanych leków przy braku dowodów na poprawę skuteczności takiego postępowania), jak i pierwszej i drugiej generacji. Chcemy jednak dodać, że w naszym przekonaniu niektórzy pacjenci mogą odnieść korzyść ze zmiany leku przeciwhistaminowego na inny, należący również do drugiej generacji.

Dokument, który przyjmujemy jako wytyczne, określa jednoznacznie miejsce omalizumabu (trzeci poziom postępowania terapeutycznego) stosowanego jako dodatkowy element dołączany do leczenia przeciwhistaminowego (lek przeciwhistaminowy drugiej generacji w zwiększonej dawce) u pacjentów, u których intensywne leczenie przeciwhistaminowe nie przyniosło pożądanego skutku. Należy zauważyć, że aktualne wytyczne donoszą o skuteczności dawek od $150 \mathrm{mg}$ do $300 \mathrm{mg}$ omalizumabu stosowanego raz w miesiącu, podczas gdy dawką zarejestrowaną w naszym kraju jest $300 \mathrm{mg}$ co 4 tygodnie. W trzecim 
poziomie schematu postępowania terapeutycznego wymieniana jest obok omalizumabu także cyklosporyna A lub ewentualnie montelukast $[1,5]$.

Wyrażamy nadzieję, że aktualne wytyczne dotyczące postępowania diagnostycznego i leczenia pokrzywki ułatwią opiekę nad tymi pacjentami i będą pomocne w Państwa codziennej praktyce klinicznej.

\section{Piśmiennictwo}

1. Zuberbier T., Aberer W., Asero R., Bindslev-Jensen C., Brzoza Z., Canonica G.W. i inni: The EAACI/GA(2) LEN/ EDF/WAO Guideline for the definition, classification, diagnosis, and management of urticaria: the 2013 revision and update. Allergy 2014, 69, 868-887.

$\begin{array}{ll}\text { Otrzymano: } & 23 \text { I } 2015 \text { r. } \\ \text { Zaakceptowano: } & 10 \text { IV } 2015 \text { r }\end{array}$
2. Zuberbier T., Asero R., Bindslev-Jensen C., Walter Canonica G., Church M.K., Giménez-Arnau A. i inni: EAACI/GA(2)LEN/EDF/WAO guideline: definition, classification and diagnosis of urticaria. Allergy 2009, 64, 1417-1426.

3. Baiardini I., Pasquali M., Braido F., Fumagalli F., Guerra L., Compalati E. i inni: A new tool to evaluate the impact of chronic urticaria on quality of life: chronic urticaria quality of life questionnaire (CU-QoL). Allergy 2005, 60, 1073-1078.

4. Brzoza Z., Badura-Brzoza K., Młynek A., Magerl M., Baiardini I., Canonica G.W. i inni: Adaptation and initial results of the Polish version of the GA(2)LEN chronic urticaria quality of life questionnaire (CU-Q(2)oL). J Dermatol Sci 2011, 62, 36-41.

5. Zuberbier T., Asero R., Bindslev-Jensen C., Walter Canonica G., Church M.K., Giménez-Arnau A.M. i inni: EAACI/GA(2)LEN/EDF/WAO guideline: management of urticaria. Allergy 2009, 64, 1427-1443. 